\title{
Analysis of Caspase- 9 protein and microRNAs miR-21, miR-126 and miR-155 related to the apoptosis mechanism in the cerebellum of rats submitted to focal cerebral ischemia associated with an alcoholism model
}

Análise da proteína Caspase-9 e dos microRNAs miR-21, miR-126 e miR-155 relacionados ao mecanismo de apoptose no cerebelo de ratos submetidos à isquemia cerebral focal associada ao modelo de alcoolismo

Jairo Pinheiro da SILVA', Fermino Sanches LIZARTE NETO', Mucio Luiz de Assis CIRINO', Camila Albuquerque Melo de CARVALHO', Carlos Gilberto CARLOTTI JR.', Benedicto Oscar COLLI', Daniela Pretti da Cunha TIRAPELLI', Luis Fernando TIRAPELLI'

\begin{abstract}
This study aimed to analyze the cerebellum of rats submitted to an experimental focal cerebral ischemia, by middle cerebral artery occlusion for 90 minutes, followed by reperfusion for 48 hours, associated with an alcoholism model. Methods: Fifty adult Wistar rats were used, subdivided into five experimental groups: control group (C): animals submitted to anesthesia only; sham group (S): animals submitted to complete simulation of the surgical procedure; ischemic group (I): animals submitted to focal cerebral ischemia for 90 minutes followed by reperfusion for 48 hours; alcoholic group (A): animals that received daily absolute ethanol diluted 20\% in water for four weeks; and, ischemic and alcoholic group $(I+A)$ : animals receiving the same treatment as group A and, after four weeks, submitted to focal cerebral ischemia for 90 minutes, followed by reperfusion for 48 hours. The cerebellum samples were collected and immunohistochemical analysis of Caspase- 9 protein and serum analysis by RT-PCR of microRNAs miR-21, miR-126 and miR155 were performed. Results: The expression of Caspase- 9 was higher in groups I, A and I + A. In the microRNAs analyses, miR-126 was higher in groups A and I + A, miR-155 was higher in groups I and I + A. Conclusions: We conclude that apoptosis occurs in the cerebellar cortex, even if it is distant from the ischemic focus, and that microRNAs 126 and 155 show a correlation with cellular apoptosis in ischemic rats and those submitted to the chronic alcohol model.

Keywords: Brain ischemia; alcoholism; cerebellum; apoptosis; microRNAs.

\section{RESUMO}

O objetivo deste estudo foi analisar o cerebelo de ratos submetidos à isquemia cerebral focal experimental, por oclusão da artéria cerebral média por 90 minutos, seguida de reperfusão por 48 horas, associada a um modelo de alcoolismo. Métodos: Foram utilizados 50 ratos Wistar adultos, subdivididos em cinco grupos experimentais: grupo controle (C): animais submetidos apenas à anestesia; grupo sham (S): animais submetidos à simulação completa do procedimento cirúrgico; grupo isquêmico (I): animais submetidos à isquemia cerebral focal por 90 minutos, seguidos de reperfusão por 48 horas; grupo alcoólico (A): animais que receberam etanol absoluto diário diluído em 20\% em água por quatro semanas; e grupo isquêmico e alcoólico $(I+A)$ : animais que recebem o mesmo tratamento do grupo $A$ e, após quatro semanas, submetidos à isquemia cerebral focal por 90 minutos, seguidos de reperfusão por 48 horas. As amostras de cerebelo foram coletadas e a análise imuno-histoquímica da proteína Caspase-9 e a análise sérica por RT-PCR dos microRNAs miR-21, miR-126 e miR155 foram realizadas. Resultados: A expressão de Caspase-9 foi maior nos grupos I, A e I + A. Nas análises de microRNAs, o miR-126 foi maior nos grupos A e I + A, o miR-155 foi maior nos grupos $\mid$ e | + A. Conclusões: Concluímos que a apoptose ocorre no córtex cerebelar, mesmo distante do foco isquêmico, e que os microRNAs 126 e 155 mostram uma correlação com a apoptose celular em ratos isquêmicos e submetidos ao modelo crônico de álcool.
\end{abstract}

Palavras-chave: Isquemia cerebral; alcoolismo; cerebelo; apoptose; microRNAs.

\footnotetext{
Universidade de São Paulo, Faculdade de Medicina de Ribeirão Preto, Departamento de Cirurgia e Anatomia, Ribeirão Preto SP, Brasil.

Jairo Pinheiro Da SILVA ID https://orcid.org/0000-0002-5213-8525; Fermino Sanches LIZARTE NETO ID https://orcid.org/0000-0002-0046-7300; Mucio Luiz De Assis CIRINO (ID https://orcid.org/0000-0001-7872-8331; Camila Albuquerque Melo De CARVALHO ID https://orcid.org/0000-0003-2325-2844; Carlos Gilberto CARLOTTIJR (iD https://orcid.org/0000-0002-7055-0564; Benedicto Oscar COLLI (iD https://orcid.org/0000-0002-0222-6770; Daniela Pretti Da Cunha TIRAPELLI (iD) https://orcid.org/0000-0002-1886-4988; Luís Fernando TIRAPELLI iD https://orcid.org/0000-0002-2251-1106 Correspondence: Luiz Fernando Tirapelli; Faculdade de Medicina de Ribeirão Preto; Av. Bandeirantes, 3900; 14049-900 Ribeirão Preto SP, Brasil; E-mail:tirapelli@fmrp.usp.br

Conflict of interest: There is no conflict of interest to declare.

Received 26 February 2019; Received in final form 25 April 2019; Accepted 07 May 2019.
} 
Cerebral ischemia is the result of decreased oxygen supply to the brain tissue ${ }^{1}$. It is considered the second largest cause of death in the world, accounting for 6.7 million deaths in 2012. In Brazil, it is the leading cause of death, followed by acute myocardial infarction. In 2014, a group of elderly people over 80 years of age represented about $37 \%$ of all deaths in both sexes. The World Health Organization estimates that by 2030, stroke will continue to be the world's second largest cause of death, representing $12.2 \%$ of deaths per year, worldwide ${ }^{2}$.

Once the interruption of oxygen supply persists, it causes several biochemical events that lead to neuronal death, and immediately to other biological events that are caused by a reperfusion process ${ }^{3}$. Cellular apoptosis is one of the events that normally occurs in the central nervous system during its development, but also occurs soon after cerebral ischemia or the influence of exogenous factors, and varies according to the magnitude of the stimulus ${ }^{4}$.

Extrinsic factors also influence cerebral ischemia, such as obesity, sedentary lifestyle, smoking, and alcoholism ${ }^{5}$.

Alcoholism affects millions of people around the world. About $10 \%$ of people in urban centers consume alcohol on a daily basis, regardless of age, sex, educational level and income. It has been proven that excessive consumption of ethanol is associated with various health risks and is responsible for a high rate of morbidity and mortality. Chronic alcohol use increases ischemic brain damage due to deficiency of cerebral vasoreactivity ${ }^{6}$.

Studies have demonstrated that microRNA (miRNA) expression may modulate neuronal survival after focal cerebral ischemia by regulating the levels of target genes that are related to the cellular apoptosis process ${ }^{7,8}$. MicroRNAs (miRNAs) are small, non-coding RNAs with the ability to regulate the expression of genes at the post-transcriptional level through the degradation or repression of translation of the molecules that are targets of messenger RNA 9 .

The miRNAs have been reported to play key roles in the regulation of molecular processes after stroke. The present study shows the complex relationship between miRNAs and stroke ${ }^{10,11 .}$

Therefore, this study aimed to analyze the cerebellar cortex of rats submitted to an experimental model of transient focal cerebral ischemia by middle cerebral artery occlusion for 90 minutes, followed by reperfusion for 48 hours, associated with a rat alcoholism model.

\section{METHODS}

The experiments were carried out in compliance with the ethical principles of the Animal Use Ethics Committee and the study was approved by the Animal Experimentation Committee of the University of São Paulo Medical School at Ribeirão Preto.
Fifty adults male Wistar rats (Rattus norvegicus), weighing approximately 200 grams (6-7 weeks) at the beginning of the experiment and 280-310 grams at the end of the experiment were used. The animals were randomly divided into five experimental groups with 10 animals each: control (C) - animals without performing the surgical procedure; sham (S) - animals submitted to complete simulation of the surgical procedure, without ischemia; ischemia (I) - animals subjected to focal cerebral ischemia for 90 minutes, followed by reperfusion for 48 hours, and then euthanized; alcohol (A) - animals receiving $20 \%$ ethanol for four weeks and then euthanized; and ischemia + alcohol $(\mathrm{I}+\mathrm{A})$ - animals submitted to the same treatment as group A as well as being submitted to focal cerebral ischemia for 90 minutes followed by reperfusion for 48 hours. Weekly measurements of the weight of the animals were performed for all study groups.

The alcoholic groups were conditioned for a brief period of gradual adaptation to the consumption of ethanol, which consisted of the supply of ethanol diluted in water, with its concentration gradually increased in weekly doses of $5 \%, 10 \%$ and 20\%; the experimental phase started at the beginning of the third week of treatment.

\section{Induction of focal cerebral ischemia}

All animals were anesthetized by inhalation with halothane and intubated with an orotracheal cannula and controlled by glycemia and blood gas parameters. Middle cerebral artery occlusion was performed through the external carotid artery, which was cranially attached and sectioned for the retrograde introduction of a 2.5-cm-long obstructive 4- 0 wire with a silicone-thickened end over a length of 5 $\mathrm{mm}$. The wire was introduced until it reached the common carotid artery and then progressed cranially through the internal carotid artery until it reached and obstructed the middle cerebral artery.

After the ischemia period, the obstructive wire was removed by placing temporary clamps on the common carotid artery and internal carotid artery to prevent blood flow reflux, and the external carotid artery proximal stump was firmly attached (4.0 Ethicon cotton thread). The skin and subcutaneous tissue were closed in the animals of groups I and I + A. Animals from these groups were euthanized after 48 hours of reperfusion. For the animals in group A, euthanasia was performed after the treatment period with $20 \%$ ethanol.

After the euthanasia, the brains were removed, and placed in a steel mold (Matrix model - ASI Instruments, CBM-2000C, USA) used to perform coronal cuts. For the immunohistochemical analysis, we used a coronal section (2 $\mathrm{mm}$ ) that was made in the middle of the cerebellum region. After obtaining the coronal section, the manual immersion solution of $4 \%$ paraformaldehyde was started in $0.1 \mathrm{M}$ phosphate buffer, $\mathrm{pH} 7.3$ at room temperature. 
Coronal sections were cut $3 \mu \mathrm{m}$ thick and prepared for immunohistochemistry for the protein expression of Caspase-9. The analysis was performed in three hot spot fields of the granular layer, molecular layer and Purkinje cells of the left cerebellar cortex and not in the glial cells. For analysis of protein expression, two fields with 400x magnification were selected, where there was a higher concentration of positive or labeled cells (hot spot areas) for each protein under study.

The samples were submitted for immunohistochemical analysis by avidin-biotin-peroxidase (Novostain Super ABC Kit - Universal, NCL-ABCu, Novocastra Laboratories Ltd, Newcastle upon Tyne, UK) (pro-apoptotic - 229 CP-B / polyclonal rabbit, Biocare Medical) diluted $1 / 300$ in $1.5 \%$ bovine serum albumin.

Samples were incubated with the MACH 4 Universal HRP-Polymer secondary antibody kit (M4BD534, Biocare Medical) and then with the same avidin-biotin-peroxidase kit (1/200 in phosphate buffered saline). Finally, the reactions were developed with diaminobenzidine solution (3.3'-diaminobenzidine tetrahydrochloride, Sigma-Aldrich, Saint Louis, Missouri, USA) and the sections were stained with Harris hematoxylin. The slides were analyzed using the Zeiss Axioskop 2 plus model with magnification of 400x. The images of the fields used for protein quantification were recorded by the camera [Axio Cam Hrc (r)] coupled under the microscope and later archived in the Axio Vision 4.6 (r) program.
For analysis of miRNA expression, $1 \mathrm{~mL}$ of blood was collected in a single moment for the four groups under study. With the real-time PCR method using the TaqMan Master Mix reagent (Applied Biosystems), the miRNA-21, miRNA126 and mi-RNA155 were analyzed.

As described, all were applied in duplicate and analyzed on the 7500 Sequence Detection System (Applied Biosystems).

The data on protein expression and immunohistochemical analysis in the various groups were statistically analyzed by the Kruskal-Wallis test, followed by Bonferroni’s post-test, using GraphPad Prism, version 5.00 for Windows, (GraphPad Software, San Diego, CA - USA). The level of significance was set at $\mathrm{p}<0.05$.

\section{RESULTS}

In the immunohistochemical analysis, the positive marking for the Caspase-9 protein was observed in all analyzed groups. Caspase-9 expression was higher in the I + A group in all the layers when compared with the other groups.

In the molecular layer in all analyzed groups, we observed a significant increase in the protein expression of Caspase- 9 $(p=0.0003)$ (Figure 1, Graph 1).

In the granular layer, a significant increase in the protein expression of Caspase- 9 was observed in the I and I + A groups when compared with the other groups $(p=0.0002)$ (Figure 2, Graph 2).

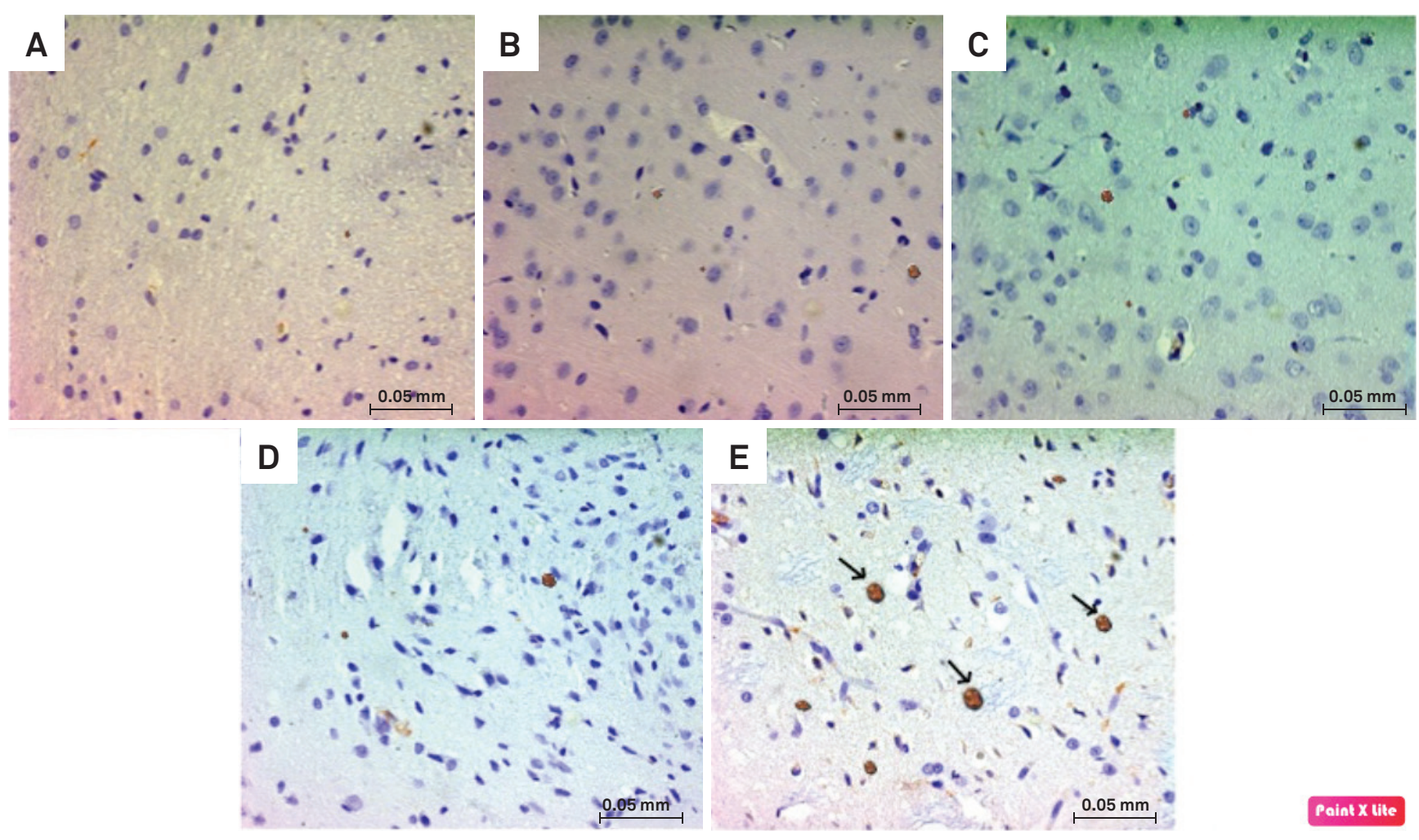

Figure 1. Photomicrograph of the molecular layer of the left cerebellar hemisphere with positive nuclear marking for Caspase-9 400x (A: Control Group, B: Sham Group, C: Ischemia Group, D: Alcohol Group, and E: Ischemia + Alcohol Group). 
In the analysis of the Purkinje cells, the comparison between the groups was statistically significant ( $p=0.008)$ (Figure 3, Graph 3).

\section{Caspase - 9 - Molecular layer}
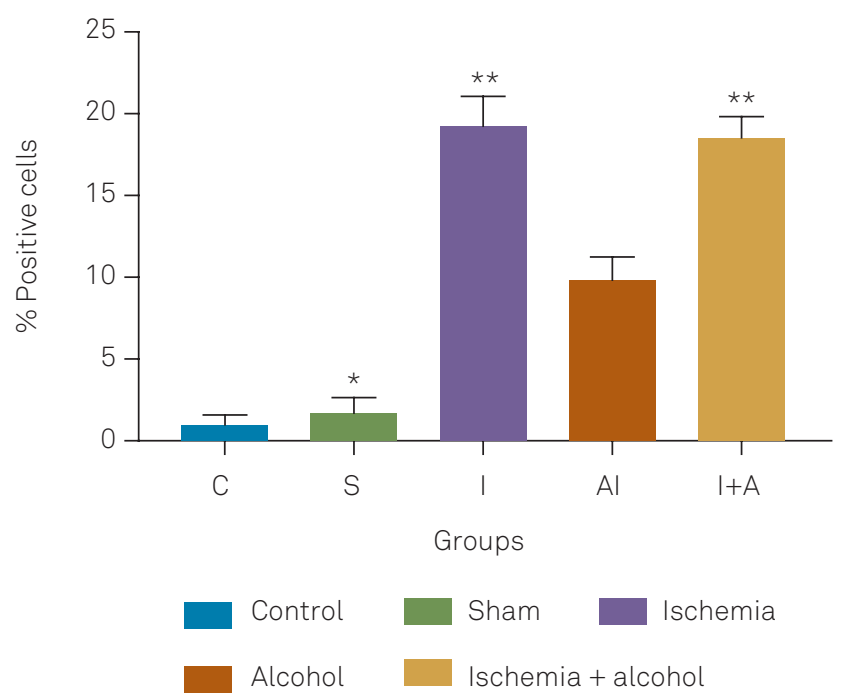

Graph 1. Statistical analysis of the percentage of positive Caspase- 9 cells in the cerebellar molecular tissue.
In the analysis of serum expression of miR-126 (Graph 4) and miR-155 (Graph 5), there were statistical significance differences between the analyzed groups ( $p=0.0006$ and 0.0002 , respectively).

There was no statistical significance in the analysis of miR-21 serum expression.

\section{DISCUSSION}

The ischemic form of cerebrovascular disease occurs in about $80 \%$ of the cases, causing sequelae that vary depending on the location and the cerebral area affected by the suppression of oxygen, as well as the time taken to attend to the patient, causing motor and/or sensory impairment, aphasia, impairment in spatial orientation and memory deficits ${ }^{12,13,14}$.

In a study using the experimental model of focal cerebral ischemia through permanent occlusion of the right common carotid artery in seven-day-old rats, the cerebellar tissue samples and brainstem samples were analyzed using the 2-deoxyuridine-5'-triphosphate-biotin nick-end labeling technique by checking the positive cells, since both sites were destroyed. In the cerebellum, positive cells were observed in the germinative layer, as well as randomly-distributed positive cells being observed in the granular layer. This positive
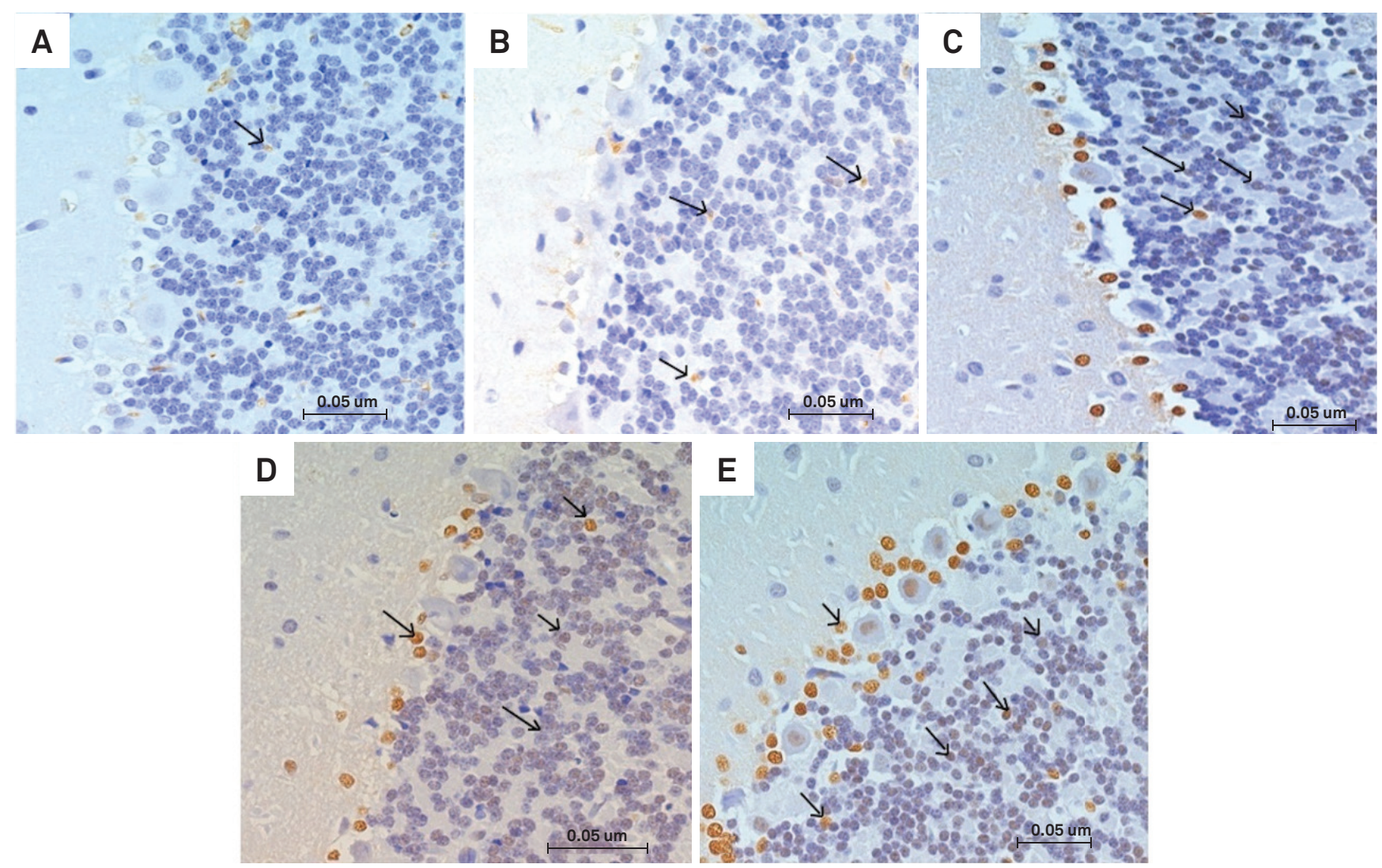

Figure 2. Photomicrograph of the granular layer of the left cerebellar hemisphere with positive nuclear marking for Caspase-9 - 400x (A: Control group, B: Sham group, C: Ischemia group, D: Alcohol group, and E: Ischemia + Alcohol group), with arrows demonstrating positive marking between groups. 
labeling demonstrates an apoptotic and necrotic coloration that was clearly distinguished in both the germ-like outer layer and the granular layer. Some cells showed necrotic morphology, cellular edema and increased size, while others
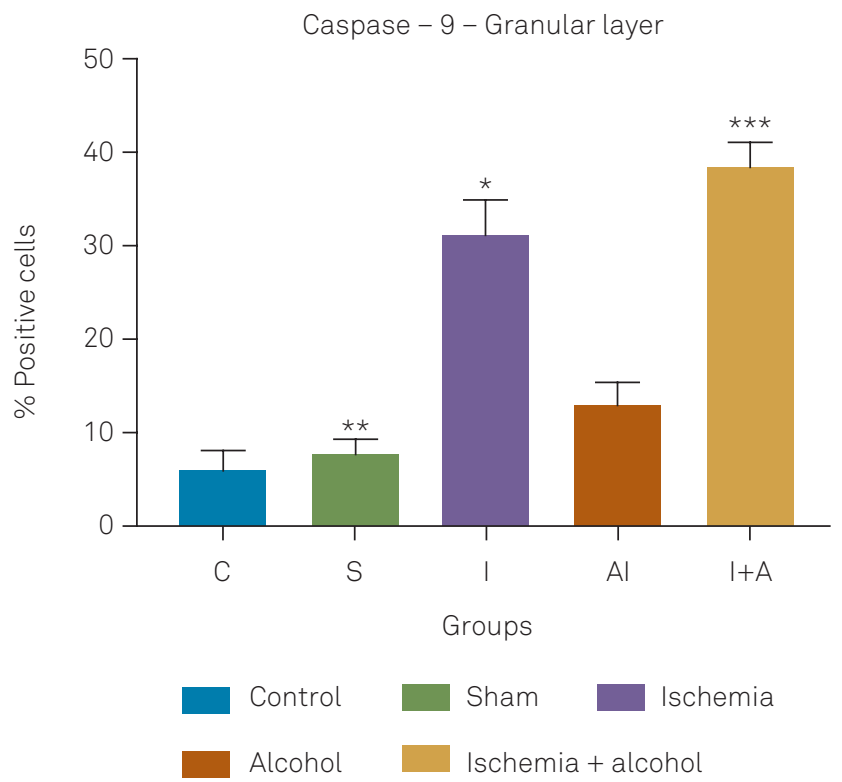

Graph 2. Statistical analysis of the percentage of positive Caspase- 9 cells in cerebellar granular tissue. were smaller with apoptotic morphology and with the presence of apoptotic bodies. In the molecular layer of the cerebellum, the number of apoptotic cells was significantly higher when compared with the necrotic cells. However, in the granular layer, the number of apoptotic cells and necrotic cells was similar. These findings indicated that the mechanism of apoptosis had been unleashed in the cerebellum and brainstem, which are regions distant from the primary ischemic region. Therefore, the authors concluded that although the cerebellum and the brainstem were outside the vascular supply of the ligated artery, these regions had undergone the actions of neurodegeneration ${ }^{15,16}$.

Studies have shown that external factors have contributed to the increased probability of occurrence of focal cerebral ischemia; among them we found genetic, hormonal and environmental factors. Among the environmental factors, we emphasize diabetes mellitus, smoking, obesity, sedentary lifestyle and alcohol abuse ${ }^{17,18}$.

The main constituent of the molecular layer is its fibers, in a parallel arrangement, and containing cells arranged either in the outer layer, region of small branched axons, or stellate cells. The granular layer consists of a large number of small nerve cells with a reduced amount of cytoplasm, called granular cells. Purkinje cells are made of large pyriform cell bodies, lying between the molecular and granular

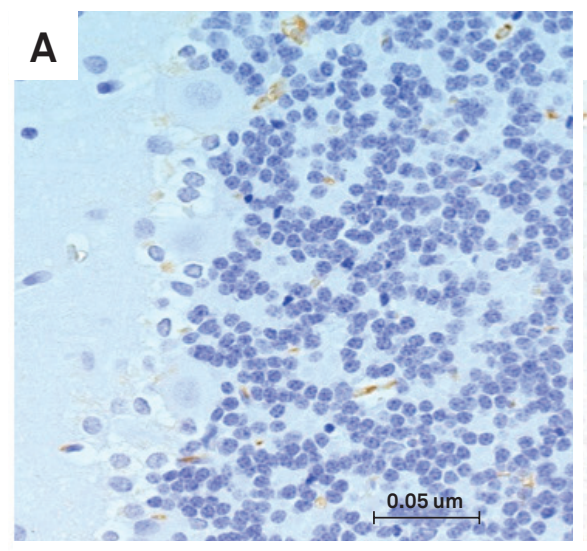

B
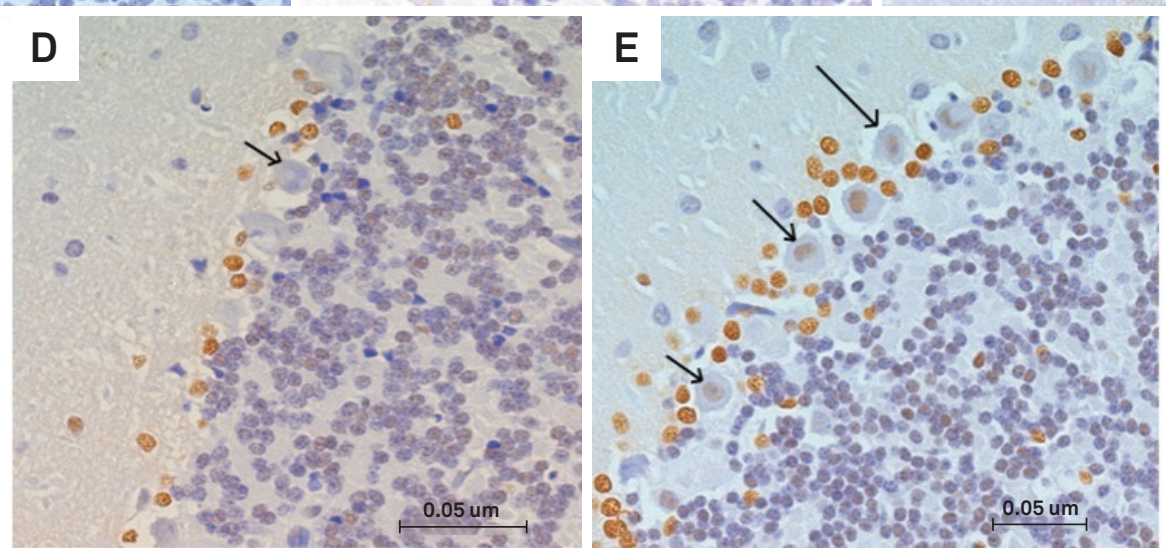

Figure 3. Photomicrograph of the Purkinje cells of the left cerebellar hemisphere with positive nuclear marking for Caspase-9 - 400x (A: Control Group, B: Sham Group, C: Ischemia Group, D: Alcohol Group, and E: Ischemia + Alcohol Group), with arrows demonstrating positive marking in Purkinje cells. 


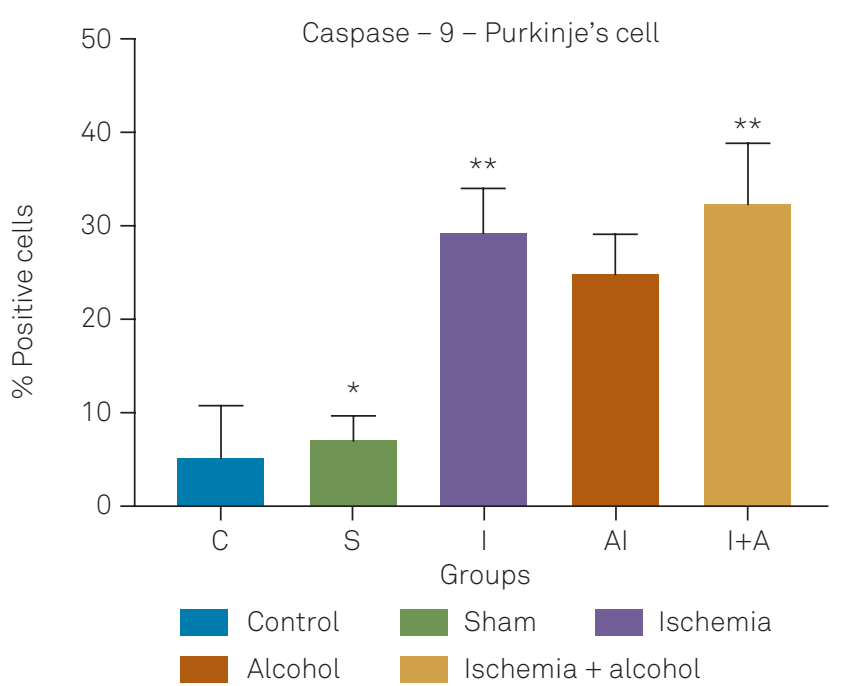

Graph 3. Statistical analysis of the percentage of positive Caspase- 9 cells in Purkinje cells in cerebellum.

layers. They have dendrites branching into the molecular layer forming a range of dendritic trees and an axon that travels into the granular layer and terminates in the central nuclei of the cerebellum ${ }^{4,19}$.

Many studies have demonstrated that miRNA expression could modulate neuronal survival after stroke by regulating target gene levels ${ }^{20}$.

In another study, miRNA-126 affected expression of stromal cell-derived factor 1 (SDF-1) in different ways. In normal endothelial cells, miR-126 repressed SDF-1 synthesis by direct binding to SDF-1 messenger RNA. The normal level of miR-126 was sufficient to modulate the expression of SDF-1 and through this molecule, vascular cell adhesion 1 . Under a high glucose condition associated with endothelial cell dysfunction, the decrease in miR-126 expression could increase SDF-1 expression and also directly affect the migration and adhesion of progenitor cells, further enhancing the outcome of stroke by cell differentiation endothelial cells ${ }^{21}$.

Among other functions of miRNAs, miR-155 is involved in the regulation of vascular and endothelial function. Its low regulation is accompanied by reduced inflammation and regeneration processes ${ }^{22,23}$. In addition to these multiple functions, miR-155 is involved in the progression of multiple CNS disorders ${ }^{24}$.

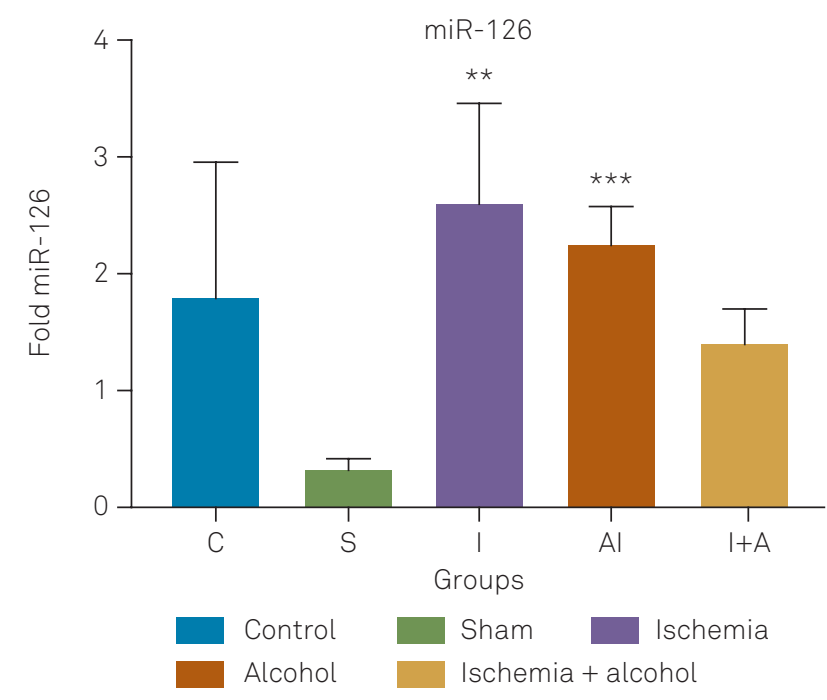

Graph 4. Mean and standard deviation of miRNA-126 serum expression between the groups studied.

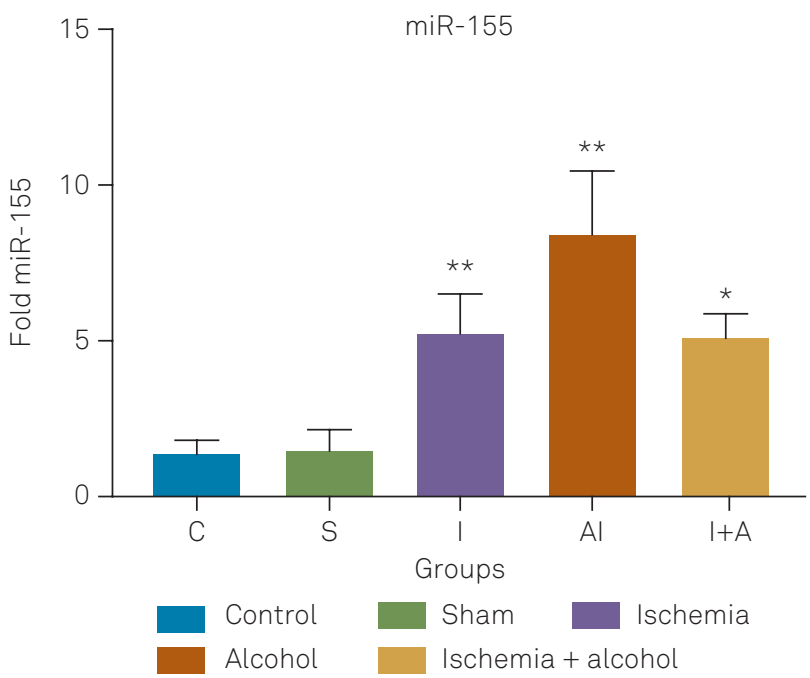

Graph 5. Representation of the mean and standard deviation of the miRNA-155 serum expression between the groups studied.

In conclusion, this work enabled us to verify the activation of the mechanism of apoptosis (by the expression of the miRNAs-126 and 155 and the Caspase-9 protein) in the cerebellum of the animals submitted to both cerebral ischemia and chronic alcoholism. However, further studies are needed to understand the role of other anti- or pro-apoptotic proteins as well as other miRNAs.

\section{References}

1. Campos-Mojena R, Marín-Prida J, Pinella-Matamoros B,

Pardo-Andreu GL, Pentón-Rol G. Isquemia

cerebral: mecanismos fisiopatológicos y oportunidades

terapéuticas. Rev Cien Farmac Aliment. 2016;2(1):1-17.

2. Sardá A, et al. Mortality Trend Due to

Cerebrovascular Accident in the City of Maringá,

Paraná between the Years of 2005 to 2015.
Int JCardiovasc Sci. 2018 Jan/Feb;31(1):56-62. https://doi.org/10.5935/2359-4802.20170097

3. Go AS, Mozaffarian D, Roger VL, Benjamin EJ, Berry JD, Blaha MJ, et al. Heart disease and stroke statistics: 2014 update: A report from the American Heart Association. Circulation. 2014 Jan;129:e28-292. https://doi.org/10.1161/01.cir.0000441139.02102.80 
4. Wu MY, Yiang GT, Liao WT, Tsai AP, Cheng YL, Cheng PW, et al. Current Mechanistic Concepts in Ischemia and Reperfusion Injury. Cell Physiol Biochem. 2018;46(4):1650-67. https://doi.org/10.1159/000489241

5. Bala S, Szabo G. MicroRNA Signature in alcoholic liver disease. Int J Hepatol. 2012;2012:498232. https://doi.org/10.1155/2012/498232

6. Bazovkina D.V et al. [The effects of chronic alcoholization on the expression of brain-derived neurotrophic factor and its receptors in the brains of mice genetically predisposed to depressive-like behavior]. Mol Biol. 2017 Jul;51(4):571-8. https://doi.org/10.1134/S0026893317040057

7. Bennett ER, Reuter-Rice K, Laskowitz DT. Genetic influences in traumatic brain injury. In: Laskowitz D, Grant G, editors. Translational research in traumatic brain injury. Boca Raton: CRC; 2016. Chapter 9.

8. McDaniel K, Herrera L, Zhou T, Francis H, Han Y, Levine P, et al. The functional role of microRNAs in alcoholic liver injury. J Cell Mol Med. 2014 Feb;18(2):197-207. https://doi.org/10.1111/jcmm.12223

9. Aguiar BA, Nonaka CFW, Freiras RA, Souza LB, Pinto LF. et al. MicroRNAs: biogênese, funções e seu papel potencial na carcinogênese oral. Odontol Clin Cient. 2010 abr-jun;9(2):105-9.

10. Carvalho CAM, Tirapelli DPC, Rodrigues AR, Lizarte Neto FS, Novais PC, Silva JP, et al. Morphological and immunohistochemical analysis of apoptosis in the cerebellum of rats subjected to focal cerebral ischemia with or without alcoholism model. 2016 Sept;31(9):629-37. https://doi.org/10.1590/S0102-865020160090000009

11. Fadda F, Rossetti ZL. Chronic ethanol consumption: from neuroadaptation to neurodegeneration. Prog Neurobiol. 1998 Nov;56(4):385-431. https://doi.org/10.1016/S0301-0082(98)00032-X

12. Xu W, Gao L, Zheng J, Li T, Shao A, Reis C, et al. The roles of MicroRNAs in stroke: possible therapeutic targets. Cell Transplant. 2018 Dec;27(12):1778-88. https://doi.org/10.1177/0963689718773361

13. Carlotti CG, Colli BO, Kazuo JY. Avaliação da isquemia cerebral pela respiração mitocondrial: Modelo experimental. Arq Neuropsiquiatr. $2001 \mathrm{JUN}$;59(2B):365-71. https://doi.org/10.1590/S0004-282X2001000300011

14. Campos WK, Guasti JA. Infarto cerebral hemisférico : algoritmo de tratamento baseado em evidência. Arq Bras Neurocir. 2011;30(2):7683. https://doi.org/10.1055/s-0038-1626497
15. Qin Y, Hu W, Uang Y, Hu Z, Li W, Fang M. Neuroprotective effect of DAHP via antiapoptosis in cerebral ischemia. Behav Neurol. 2018;:5050469. https://doi.org/10.1155/2018/5050469

16. Thapalia BA, Zhou Z, Lin X. Autophagy, a process within reperfusion injury: an update. Int J Clin Exp Pathol. 2014 Dec;7(12):8322-41.

17. Kanda T, Matsuoka S, Yamazaki M, Shibata T, Nirei K, Takahashi H, et al. Apoptosis and non-alcoholic fatty liver diseases. World J Gastroenterol. 2018 Jul;24(25):2661-72. https://doi.org/10.3748/wjg.v24.i25.2661

18. Liu B, Zhang Y, Jiang Y, Li L, Li C, Li J. Electrical stimulation of cerebellar fastigial nucleus protects against cerebral ischemic injury by PPAR u upregulation. Neurol Res. 2017 Jan;39(1):23-9. https://doi.org/10.1080/01616412.2016.1251710

19. Moon, J. M.; Xu, L.; Giffard, R. G. Inhibition of microRNA-181 reduces forebrain ischemia-induced neuronal loss. J Cereb Blood Flow Metab. 2013 Dec;33(12):1976-82. https://doi.org/10.1038/jcbfm.2013.157

20. Wang J, Dong WW, Zhang WH, Zheng J, Wang X. Electrical stimulation of cerebellar fastigial nucleus: mechanism of neuroprotection and prospects for clinical application against cerebral ischemia. CNS Neurosci Ther. 2014 Aug;20(8):710-6. https://doi.org/10.1111/cns.12288

21. Adams JM. Ways of dying: multiple pathways to apoptosis. Genes Dev. 2003 Oct 15;17(20):2481-95. https://doi.org/10.1101/gad.1126903

22. Cho YE, Yu LR, Abdelmegeed MA, Yoo SH, Song BJ. Apoptosis of enterocytes and nitration of junctional complex proteins promote alcohol-induced gut leakiness and liver injury. J Hepatol. 2018 Jul;69(1):142-53. https://doi.org/10.1016/j.jhep.2018.02.005

23. Ladeiro Y, Couchy G, Balabaud C, Bioulac-Sage P, Pelletier L, Rebouissou S, et al. MicroRNA profiling in hepatocellular tumors is associated with clinical features and oncogene/tumor suppressor gene mutations. Hepatology. 2008 Jun;47(6):1955-63. https://doi.org/10.1002/hep.22256

24. Xie YL, Zhang B, Jing L. MiR-125b blocks Bax/Cytochrome C/ Caspase-3 apoptotic signaling pathway in rat models of cerebral ischemia-reperfusion injury by targeting p53. Neurol Res. 2018 Oct;40(10):828-37. https://doi.org/10.1080/01616412.2018.1488654 